\title{
Assessment of the impact of Smartphone Technology on Tour Guide Performance in Kenya
}

\author{
Kabii Francis \\ Corresponding author \\ Lecturer, Tourism Department, Kenya Utalii College, Nairobi, Kenya \\ E-mail: fkabii@utalii.ac.ke \\ John K. M. Wandaka (Ph.D) \\ Deputy Director of Studies, Kenya Utalii College, Nairobi, Kenya \\ E-mail: wandakaj@gmail.com
}

Naghea Jilo

Research Assistant, Kenya Utalii College, Nairobi, Kenya

E-mail: njilo@utalii.ac.ke

Received: July 3, 2019 Accepted: August 1, 2019 Published: September 7, 2019

doi:10.5296/ijssr.v7i2.15406 URL: http://dx.doi.org/10.5296/ijssr.v7i2.15406

\begin{abstract}
Several studies have been conducted to examine the influence of technology on the travel and tourism industry. However, there exists limited literature on the adaptation and usage of Smartphone technology by Kenyan tour guides, a gap this study sought to address. The objective of the study was to examine the effect of Information Communication Technology (ICT) on tour guiding performance in Kenya, investigate the effect of smartphone usage on the guides' performance and finally, explore the possibility of adoption smart guiding techniques by Kenya's tour guides. The study used descriptive methods and target practicing tour guides as the respondents. The data collected was analyzed using the Pearson's Chi-square test of independence. The findings indicated Smartphone technology positively influenced guides, performance $\left(\chi^{2}=65.025 ; \mathrm{df} 2 ; \mathrm{P}<0.05\right)$. The study concluded that smartphone and information communication technology have significantly influenced guides performance and hence recommend to the government and other stakeholders to invest more
\end{abstract}




\section{Macrothink}

International Journal of Social Science Research

ISSN 2327-5510

in infrastructure that supports smart destinations, which offer interactive pre-tour services, during the tour and post-tour experiences. Innovation on applications that support real-time interaction with attractions, accommodation and financial institutions is recommended.

Keywords: Smartphone Technology, Tour Guide, Adaptation, Performance 


\section{Introduction}

The mobile phone technology has not only become the most important communication technology worldwide, but also offers many additional functions such as access to the internet, audio-visual recordings or financial transactions. Mobile technology has been used to improve the delivery of services by tour guides in Kenya. Various authors have examined the technology trends that are likely to shape the use of information and communication technologies (ICT) in the future (Katz, 2017; Andrae \& Edler, 2015; Martin, 2017). However, an analysis of how these trends may be relevant to tour guides and visitors to a destination is limited. To help close these knowledge gaps, this study tries to identify the mobile phone technology and its influence on the guide's performance. The findings from this research will assist service providers to assess the utility levels of new mobile technologies, not only by the tour guides but also other stakeholders in the tourism and hospitality industry. The study intends to inform the stakeholders on the smartphone uses by guides and the required support infrastructure with the main aim being to improve the service quality offered to the visitors.

The objectives of this study were as therefore to;

1) Examine the effect of Information Communication Technology (ICT) on tour guiding performance in Kenya

2) Examine the effect of smartphone usage on the guide's performance.

3) Explore the possibility of adopting smart guiding by Kenya's guides and visitors

Literature indicates that one of the biggest innovations in the $21^{\text {st }}$ century is the internet. Available data show that by 2018 there were 4 billion active internet users of which 3.3 billion are active in social media. Information from Communication Authority of Kenya (CAK) (2018) indicates that the mobile broadband has become accessible in Kenya where a total of 42 million internet subscription was reported in the year 2018. Kenya has experienced rapid growth over the last decade, with the ICT sector expanding from $10 \%$ to $22 \%$ in 2017 , contributing to $1.6 \%$ of total GDP. While Smartphone use is on the rise in developing countries, penetration rates differ widely.In 2017 Mobile adoption in Kenya was 91\% $(46.94 \mathrm{~m})$ penetration of mobile subscriptions, compared to $80 \%$ mobile penetration in Africa and internet connectivity, at a penetration rate of $84 \%$ with $43.3 \mathrm{M}$ of the total population having access to the Internet in Kenya.(https://www.jumia.co.ke/mobile-report)

\section{Literature Review on Smart Tour Guiding}

There is no consensus of definition on smart tourism, but those who have defined it agrees that it is based on Internet of Things (IoT), cloud computing,mobile communication and artificial intelligence communication ( Gretzel et al., 2015; Li et al., 2017; Del Vecchio et al., 2018). Smart tourism has been regarded as the second revolution to the tourism industry, the first one being the internet innovation (Rayman-Bacchus \& Molina, 2001 and Kitchin, 2014). The smart tourism has brought about application integrations and generation of new ICT which has affected the traveller's behaviour, consumer expectations and interactions within a destination visited, and finally the tourism business operation model in most parts of the world 
including Kenya.

Smartphone and other hand-held devices has become a portal through which information can be seamless accessed. Through sensors from smartphones, visitos can access big data, open data and share through their phones. Some destinations have been referred to as smart destinations due to their heavy investment in ICT integration, networking and physical infrastructure that support smart tourism. Example of such destination on is Barcelona city that has an interactive bicycle and bus shelters which gives visitors schedules and availability of bicycles for transport (Cichosz, 2013). The city of Amsterdam also has technology that translates road signs into different languages (Hardman, 1994).

Smart tourism enables visitors to have smart experience and enhances personal holiday experience where visitors can upload photographs through shared Instagram and other platforms. Visitors can with the help of their smartphone access and share information from destination systems. The systems are aimed to support travelers' by anticipating their needs, help them make choices of their consumption habits thus enhancing visitors experience through offering customized interactive services and enabling them to share their experience. The concept of smart destination is gradually taking shape in Kenya and the government and some stakeholders are investing heavily on the required infrastructure. Such innovation can be seen in the mobile telecom Safaricom Mpesa, a mobile money transfer application which has transformed transfer of money in Kenya and other parts of the world (Aker \& Mbiti, 2010; Hughes \& Lonie, 2007; Mas \& Morawczynski, 2009).

\subsection{Smart Technology and Tour Guiding}

The mobile phone technology is currently used not only as a communication tool but also as an information search tool, provision for location services and information required by visitors anytime and anywhere. The location dependent applications have become more popular in the mobile computing environment and travellers can now schedule reminders on their phone which are triggered once they reach the location. What only is required is for the phone to report their location to a server so that they can query the information they want. The advantage of the use of smartphone interaction is that the user does not require extra equipment other than the phone (CAK, 2018).

There are different types of mobile digital application in tourism which may be recommended to any destination. The first categories are the Transport planning applications which are designed to allow users to track flight information in many locations in real time, helping them to share information on travel. Examples of such successful applications include TripIt, a travel itinerary website for organizing vacations, group trips or business travel (Kesselman. 2017; Model \& Heritage, 2017), TripCase application, which allows users to book flight itineraries, hotel bookings, and rental car reservations (Emrouzeh et al., 2017), Trip deck (Kazez, 2010), Cloudbeds'Reservation System (Jaatinen \& Kinnunen, 2017), eZee Frontdesk used by boutique hotels, lodges, resorts, and small hotels (Grotte, 2018) and Maestro's dashboard (Klein et al., 2013) 
Likewise, the Event listings applications allow users to upload or download information on events and activities in their current location and to recommend places and events. The Travel planner applications perform integrated itinerary management functions including flights and car hire, hotel and restaurant reservations. Visitors can use this application to plan for their own itinerary in a given destination, and seek the assistance of a tour consultant once in a destination. This is normally used to organize independent tours (Gavalas et al., 2014).

Accommodation planning applications function as a location-based tourist information center service for accommodation and are used by visitors to plan and book their accommodation through the internet an example being Booking.com. (Berger et al., 2002; Lehmann \& Lehner, 2002). Also available to users are the Tour guide applications, which consist of city guides containing recommendations for restaurants, shopping, attractions, and nightlife. They are gradually replacing the tourist guide maps to a destination with an aim of reducing paperwork. Other forms of mobile digital applications used by guides are directional services such as Google map and Global Positioning System (GPS).

The GPS has become a tool that provides location details where the satellite broadcasts signals from space, which are picked up and identified by the receiver giving the latitude, longitude and altitude of a location. Attraction applications enhance the visitor experience at a particular site or attraction such as museums and historical and archaeological site. These applications are interactive and the visitor using mobile phone can get information in a destination (Guttentag, 2010).

Different countries have innovated mobile technologies that assist tour guides. Examples of such application are MobiDENK a mobile, a location-aware information system that draws the visitor's attention to historic sites of interest and provides location-dependent multimedia information. MobiDENK also offers visual navigation support (Krösche \& Boll, 2005), SightSeeing $4 U$ a multimedia web offers personalized multimedia content and related functionality to the client applications (Li et al., 2009), and finally Mobile Travel Buddy, an application that gives information on the capital cities, population and other tourist-related services in a location (Ismail et al., 2016)

This study proposes that the Kenyan government and other stakeholders in tourism can explore the possibility of investing in some of these applications with the aim of serving the customer better and transforming Nairobi to a smart city. The success of some of these smart applications in Kenya is the Uber taxi services, which can be said to have changed the taxis business in Kenya. Unlike the traditional taxis operators, you can today use your smartphone download an application that makes it possible for one to request Uber services in the comfort of your home and be notified when the driver arrives. This shows that the destination is ready for uptake of any application that improves delivery of services.

\section{Study Methodology}

This study was descriptive and targeted tour guides from different parts of the country who were randomly sampled to attend their annual training at Kenya Utalii College, one of the leading tourism and hospitality training institutions in Africa. The judgmental sampling 
method was used. The criteria to participate in this study was that one should have at least three years of work experience and registered as a guide in Kenya. The target populations were tour guides. The sample size was 56 respondents. The data was collected using a questionnaire and interviews. Both qualitative and quantitative data was collected and was later analyzed using descriptive statistics while the relationship was analyzed using Chi-Square test of independence and Chi-Square Goodness of Fit was used to examine the observed and the expected frequency for most of the responses. Field observations by the authors, who have interacted with Kenyan tour guides for over twenty years, were used to corroborate the findings.

\section{Findings and Discussions}

The majority of the respondents (54\%) were freelance tour guides as compared to $44 \%$ who were on full-time employment. About $34 \%$ owned the tour vehicles as compared to $64 \%$ who drove company vehicles. Majority of them $84 \%$ were not affiliated to Kenya Association of Tour Operators (KATO). All of them owned Smartphones and 88\% indicated that they needed more training on how they can effectively use most features on their Smartphones.

Since most visitors to Kenya are interested in viewing wildlife, technological investment in the vehicles is very important. The study sought to examine how much technological innovation is available in the tour vehicles. The study observed that the majority $(90 \%)$ of the respondents said that their vehicles have a VHF radio while $88 \%$ of the said that their vehicles have a battery and phone charger. The results showed that half of the respondents had WIFI in their vehicle meaning visitors would access the internet. There is limited Internet penetration in some accommodation in the wilderness areas. About $83 \%$ of respondents have car track systems in their vehicles. In relation to adaptation and usage of the smartphone, the majority (71\%) admitted that they are not using most features in their smartphones. About $88 \%$ of them said they needed more training on the application of technology in guiding. Although most guides would download some application that would help, them a good number were not able.

\subsection{Tour Guides and Their Preferred Social Media}

Nearly, all tour guides had a mobile phone. Some of them have a Smartphone which is not only used for communication but to perform other duties with the desire of improving the quality of services offered. Smartphone technology influence their communication and performance. The majority $(76 \%)$ of the tour guides stated that technology had significantly improved their performance. This study noted that most guides use social media as a mode of communication the most famous being WhatsApp (98\%) followed by email (95\%). The least mode of social media used by the guides was twitter (20\%), Linked In(22\% and Instagram (39\%).This finding is close to that of Jumia Mobile Report 2019, which indicated that most Kenyans used WhatsApp (74\%), Facebook (70\%) \& Twitter (50\%) as their preferred social media (https://www.jumia.co.ke/mobile-report)

There was a significant relationship between guides performance and their usage of social media such Instagram $\left(\chi^{2}=9.065 \mathrm{df}=4, P=0.059\right)$ and LinkedIn $\left(\chi^{2}=7.920, \mathrm{df}=4, P=0.095\right)$. 


\section{Macrothink}

The findings indicated that although respondents regarded Instagram as the best platform for sharing photographs of wild animals, most of them preferred using WhatsApp as seen in Figure 1.

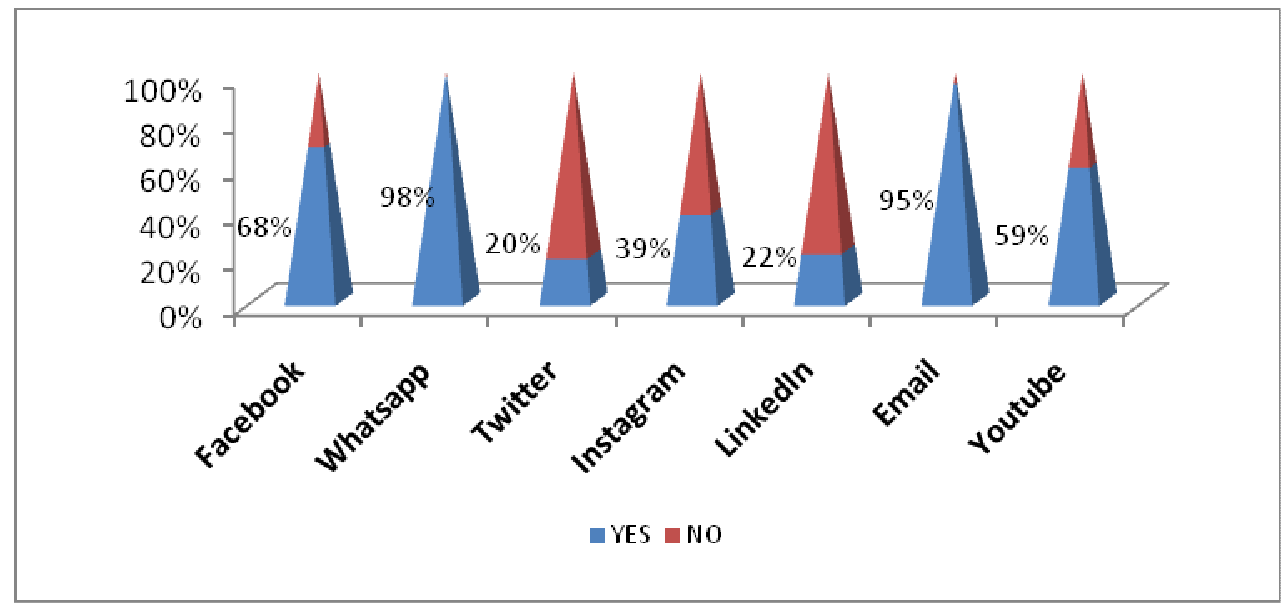

Figure 1. Preferrred social media by tour guides

\subsection{Influence Smartphone Features on the Guides'Performance}

The smartphone can be viewed as the most powerful and influential technology in the guiding career. Due to advanced technologies on Smartphone computing, storage, and transmission capabilities, a tour guide in Kenya have taken advantage of their features in improving the services. The features that most guides use were cameras, Geographical Information's Systems and location indicator. The study sought to examine the usage of phone cameras and its influence on their performance. The respondents were required to indicate how cameras have influenced their performance. The majority (44\%) indicated that they used cameras while $46 \%$ said they use their phones for booking and payments of services as compared to $59 \%$ who use their phone sound amplifiers when guiding. Quite a number of the respondents used their cameras to take photos, weather forecasting when guiding and Global Positioning Systems (GPS) when driving. Most of them agreed that innovations in Smartphone have tremendously improved communication and service delivery.

\subsection{Features of the Smartphone Used by the Guides}

The Kenya Economic Survey Report of 2017/2018 indicated that in 2018, the number of active mobile subscriptions in Kenya stood at 46.6 million. The Guides were asked to indicate use of features that their smartphones and how they influenced their performance. All (100\%) agreed that smartphones had download applications that they used when guiding. The majority used Bluetooth (95\%), location indicator (93\%), Global Positioning Systems $(83 \%)$ and Video player features. Other features that were of importance were; transport application, and booking and payments applications. This finding shows that most of them 
were using their smartphone to perform their normal duties thus enhancing the quality of services given to the visitors.

\subsection{Tools Offered to Visitors While in a Tour}

The way the tour guide is prepared for a tour determines the quality of services he offers to the visitors. The study sought to investigate the tools they give to visitors while on tour. The majority $(83 \%)$ indicated that they have binoculars with only $7 \%$ of them offering night goggles required for night game drives. Although sometimes some visitor has hearing challenges, only 7\% offer Assistive Listening systems. Other facilities and equipment that were lacking were cameras with zoom lenses (71\%) sound receivers and headphone, and voice amplifiers. The results show that availing night goggles $\left(\chi^{2}=29.878 \mathrm{df1} \mathrm{P}<0.05\right)$, voice recorder $\left(\chi^{2}=65.025 \mathrm{df} 2 \mathrm{P}<0.05\right)$ and transmitters $\left(\chi^{2}=55.073 \mathrm{df} 2 \mathrm{P}<0,05\right)$, guide books and zoomed cameras significantly influenced guides performance, as illustrated on Table 1 below.

Table 1. Smartphone features used by guides to improve their performance

\begin{tabular}{|c|c|c|c|c|c|c|c|c|}
\hline & $\begin{array}{l}\text { Night } \\
\text { goggles }\end{array}$ & $\begin{array}{l}\text { Assistive } \\
\text { Listening } \\
\text { systems }\end{array}$ & $\begin{array}{l}\text { Individual } \\
\text { Voice } \\
\text { recorder }\end{array}$ & $\begin{array}{l}\text { Voice } \\
\text { Transmitters } \\
\text { and } \\
\text { Microphone }\end{array}$ & $\begin{array}{l}\text { Camera } \\
\text { with } \\
\text { zoom } \\
\text { lenses }\end{array}$ & $\begin{array}{l}\text { Sound } \\
\text { receivers } \\
\text { and } \\
\text { Headphones }\end{array}$ & $\begin{array}{l}\text { Electronic } \\
\text { Guide } \\
\text { books }\end{array}$ & $\begin{array}{l}\text { Voice } \\
\text { amplifiers }\end{array}$ \\
\hline Chi-Square & $29.878^{\mathrm{a}}$ & $59.902^{b}$ & $65.024^{b}$ & $55.073^{b}$ & $7.049^{\mathrm{a}}$ & $33.390^{\mathrm{a}}$ & $23.439^{\mathrm{a}}$ & $37.098^{\mathrm{a}}$ \\
\hline df & 1 & 2 & 2 & 2 & 1 & 1 & 1 & 1 \\
\hline Sig. & .000 & .000 & .000 & .000 & .008 & .000 & .000 & .000 \\
\hline
\end{tabular}

a. 0 cells $(0.0 \%)$ have expected frequencies less than 5 . The minimum expected cell frequency is 20.5 .

b. 0 cells $(0.0 \%)$ have expected frequencies less than 5 . The minimum expected cell frequency is 13.7 .

\subsection{Use of Internet Technology by the Guides}

The study also noted that the increasing availability of affordable Smartphones and cheap data bundles played a major role in facilitating Internet penetration by guides. This demand for Internet use has also been influenced by the growth of social networking, e-commerce, digitization of government services and online research activities. About 90 percent of Internet subscribers could access Internet via mobile phones by 2018 (CAK, 2018).

The results indicated that most guides use the internet as a major source of information when guiding. Some $(66 \%)$, respondents used it to market themselves, share photos and videos of wildlife, get travel updates $(71 \%)$ and research $(90 \%)$. Majority of them $(85 \%)$ used the internet to get destination information, while $90 \%$ used the internet to download videos. According to CAK (2018), the increasing demand for and uptake of mobile services such as mobile money, mobile internet, mobile Apps, mobile banking, marketing and gaming had resulted to a significant increase in the number of mobile services subscriptions which was 45.5 million in March 2018(CAK, 2018) 
4.6 Opportunities and Gaps that Guides Can Use to Improve Their Performance

Information of geospatial location of wildlife and their distribution in the wilderness is missing. Most national parks and reserves have a lot of information on geo-spatial distribution and location of flora and fauna, currently there no Smartphone interactive application for guides and visitors. Such applications are available in other countries and with infrastructure development, this is also possible in Kenya.

Interpretation of attractions en-route to the tourist attraction is an effective way of enhancing the visitor's experience. When guides are driving within the city and along the route to the tourist attractions, there are many areas where they make stop-overs. An example of such places is the Great Rift Valley view point near Limuru town and Shetani Lava Flow in Tsavo West. Although there are signposts interpreting such sites, there are no provisions for visitors and guides to interact with the interpretation posts.

Today's visitors to archaeological and historical sites and museums in Kenya have to walk around these sites and read interpretations boards for each specimen. The assumption is that all visitors can read and understand the English language. This is not always the case and visitors are therefore forced to get the assistance of host guides. With an application that alerts the guides and visitors the presence of attraction and interpretation information, this would improve the customer experience since the interaction can be translated into different languages. Smartphone technologies application would, therefore, be highly recommended.

\section{Conclusions and Recommendations}

The study found that tour guides in Kenya have adapted to technology and has improved their performance. Most guides have Smartphones with which the users access the internet. However, the usage of the Smartphone was more effective in areas that were accessible with their $4 \mathrm{G}$ internet providers. It was observed that tour companies are connecting their vehicles to WIFI which is used by both the guides and the visitors. Guides use social media to communicate and socialize, and most have social groups within which they discuss and share experiences and challenges. Adaptation of ICT is gradually replacing their VHF radio and most communication is done through the phone. The infrastructure in the Kenyan national parks and reserves does not support internet accessibility limiting the usage of the phone in the wilderness. This is not the same as in towns where internet is readily accessible.

The cameras in the smartphone are one of the features that have immensely improved their quality of the photos which through technology is shared with colleagues and visitors on the social platform. Although most phones have several features, some are hardly used. Location features maps GPS are among the ones not often used. The researcher's findings indicate that these features would be important mostly when a guide wants to locate an animal of interest using the coordinates. The cost of a good Smartphone, internet distribution, cost of internet bundles, battery life were some of the challenges that limited the usage of the phone.

As a destination, the internet market is expected to continue growing considering the government initiatives that are already in place such as the development of the Konza Techno City, setting up more ICT hubs and continuous implementation of broadband projects aimed 
at providing more Internet connectivity. The ongoing voice infrastructure projects by the Communications Authority of Kenya under the Universal Service Fund are also expected to boost availability and access to mobile services especially in marginalized areas usually considered by service providers as economically unviable

After such projects are actualized, the destination can have smart services that visitors can use to get information on accommodation, interact with attraction such as museums with the use other tourism-related applications as those discussed in the paper. Report from the National Cybersecurity Centre detected over 3.4 million cyber threats in 2018 alone which composed of, online fraud, online impersonation and online abuse attacks (CAK, 2018) This threats if not managed may limit the growth of ICT in Kenya and the idea of a smart destination. This study recommends further studies on infrastructural developments needed in the destination to facilitate the use of interactive tourism applications. Policy guidance on usages of such applications is highly recommended. As illustrated from the findings of this study, technology is changing the quality of services given by the guides and the tourism industry is ready for smart tourism.

\section{References}

Aker, J. C., \& Mbiti, I. M. (2010). Mobile phones and economic development in Africa. Journal of Economic Perspectives, 24(3), 207-32. https://doi.org/10.1257/jep.24.3.207

Andrae, A., \& Edler, T. (2015). On global electricity usage of communication technology: trends to 2030. Challenges, 6(1), 117-157. https://doi.org/10.3390/challe6010117

Berger, S., Lehmann, H., \& Lehner, F. (2002). Location-based services in the tourist industry. Information Technology \& Tourism, 5(4), 243-256. https://doi.org/10.3727/109830503108751171

Chin, D., Smith, B., Palm, L., Hoefele, C., Mora, S., Smith, C., ... \& van de Wijgerd, J. (2010). More IPhone Cool Projects: Cool Developers Reveal the Details of Their Cooler Apps. Springer. https://doi.org/10.1007/978-1-4302-2923-0

Cichosz, M. (2013). IT solutions in logistics of smart bike-sharing systems in urban transport. Management, 17(2), 272-283. https://doi.org/10.2478/manment-2013-0071

Communication Authority of Kenya (CAK). (2018). First Quarter Sector Statistics Report For the Financial Year 2018/2019.

Del Vecchio, P., Mele, G., Ndou, V., \& Secundo, G. (2018). Creating value from social big data: Implications for smart tourism destinations. Information Processing \& Management, 54(5), 847-860. https://doi.org/10.1016/j.ipm.2017.10.006

Emrouzeh, M. P., Dewar, K., Fleet, G., \& Bourgeois, Y. (2017, September). Implementing ICT for Tourists with Disabilities. In Proceedings of the 2017 International Conference on E-Education, E-Business and E-Technology (pp. 50-53). ACM. https://doi.org/10.1145/3141151.3141152

Gavalas, D., Konstantopoulos, C., Mastakas, K., \& Pantziou, G. (2014). Mobile recommender 
systems in tourism. Journal of network and computer applications, 39, 319-333. https://doi.org/10.1016/j.jnca.2013.04.006

Gretzel, U., Sigala, M., Xiang, Z., \& Koo, C. (2015). Smart tourism: foundations and $\begin{array}{llll}\text { developments. } \quad \text { Electronic } & \text { Markets, } & \text { 25(3), }\end{array}$ https://doi.org/10.1007/s12525-015-0196-8

Grotte, J. (2018). Future Challenges of the Hospitality Industry (7th ed.).

Guttentag, D. A. (2010). Virtual reality: Applications and implications for tourism. Tourism Management, 31(5), 637-651. https://doi.org/10.1016/j.tourman.2009.07.003

Hardman, L., Bulterman, D. C., \& Van Rossum, G. (1994). The Amsterdam hypermedia model: Adding time, structure and context to hypertext. Communications of the ACM, 37(2), 50-62. https://doi.org/10.1145/175235.175239

Ismail, A., Kadir, S. A. S. A., Aziz, A., Mokshin, M., \& Lokman, A. M. (2016, August). tourism travel buddy mobile application. In 2016 10th International Conference on Next Generation Mobile Applications, Security and Technologies (NGMAST) (pp. 82-87). IEEE. https://doi.org/10.1109/NGMAST.2016.22

Jaatinen, M., \& Kinnunen, J. (2017). The potential of virtual and augmented reality on the Finnish tourism market.

Kaplan, E., \& Hegarty, C. (2005). Understanding GPS: principles and applications. Artech house.

Katz, J. E. (2017). Machines that become us: The social context of personal communication technology. Routledge. https://doi.org/10.4324/9780203786826

Kesselman, M. (2017). Conference report: 50th consumer electronics show. Library Hi Tech News, 34(3), 1-8. https://doi.org/10.1108/LHTN-03-2017-0014

Kitchin, R. (2014). The real-time city? Big data and smart urbanism. GeoJournal, 79(1), 1-14. https://doi.org/10.1007/s10708-013-9516-8

Klein, C., Maggio, M., Årzén, K. E., \& Hernández-Rodriguez, F. (2013). Resource management for service level aware cloud applications. In International Workshop on Real-time and Distributed The 2nd International Workshop on Real-Time and Distributed Computing in Emerging Applications (Co-located with 34th IEEE Real-time Systems Symposium). IEEE Computer Society.

Krösche, J., \& Boll, S. (2005, May). The xPOI concept. In International Symposium on Locationand Context-Awareness (pp. 113-119). Springer, Berlin, Heidelberg. https://doi.org/10.1007/11426646_11

Li, Q., Li, S., \& Pan, G. (2009, June). ScudMobile: A context-aware information service system for car touring in the city-wide area. In 2009 IEEE Intelligent Vehicles Symposium (pp. 1413-1418). IEEE. https://doi.org/10.1109/IVS.2009.5164492 


\section{Macrothink}

International Journal of Social Science Research

ISSN 2327-5510 2019, Vol. 7, No. 2

Li, Y., Hu, C., Huang, C., \& Duan, L. (2017). The concept of smart tourism in the context of tourism information services. Tourism Management, 58, 293-300. https://doi.org/10.1016/j.tourman.2016.03.014

Martin, W. J. (2017). The global information society. Routledge. https://doi.org/10.4324/9781315239385

Mas, I., \& Morawczynski, O. (2009). Designing mobile money services lessons from M-PESA. Innovations: Technology, Governance, Globalization, 4(2), 77-91. https://doi.org/10.1162/itgg.2009.4.2.77

Rayman-Bacchus, L., \& Molina, A. (2001). Internet-based tourism services: business issues and trends. Futures, 33(7), 589-605. https://doi.org/10.1016/S0016-3287(01)00003-9

\section{Copyrights}

Copyright for this article is retained by the author(s), with first publication rights granted to the journal.

This is an open-access article distributed under the terms and conditions of the Creative Commons Attribution license (http://creativecommons.org/licenses/by/4.0/). 